\title{
The Body of the Condottiero. A Link Between Physical Pain and Military Virtue as it was Interpreted in Renaissance Italy
}

\author{
GIULIA MOROSINI
}

Within the context of this conference about the body in the Middle Ages, I would like to analyse the symbolic function of the body, and in particular wounds and mutilations, had for the Italian military class in the Renaissance. Therefore, I asked myself the following questions: did wounds and scars have a specific meaning in the military mentality of the Renaissance? If the answer is yes, with what connotation? Did they rely on a moral system which identified the positive and negative characteristics of the military action? In the space of this article I shall attempt to answer to these questions, well aware of the fact that this subject needs, due to its extent, a wider documentary spectrum. This article aims only to be a preliminary and exploratory work, with the intent to offer some starting points for a consequent reflection. Within the tight space allowed, it is not possible to deeply investigate the mass of more and less famous condottieri who populated Italy during the XV century. Therefore, I preferred to focus my attention on four characters, who cover a time frame from the beginning of the XV century until the first years of the XVI century, namely Braccio da Montone, Sigismondo Malatesta, 
Federico di Montefeltro and Giovanni de' Medici. ${ }^{1}$ Although they differ extremely with respect to temperament and personal and political history, these characters represented the excellence of the contemporary military class of Italian condottieri. For each of these captains I refer in particular to the commentarii of their lives, to personal letters, to Renaissance literature and to coeval chronicles. ${ }^{2}$ If the subject is considered from a factual angle, the document's selection, and the exclusion of political and government sources, may seems a little incomplete to meticulously retrace events, battles and military strategies. The selected sources, instead, can be enlightening if they are considered not for the accurate narration of the events, but for the stylistic elements which were used to consecrate the condottiero to posterity. Through the identification of recurrent themes within the condottieri's eulogies it is possible to reconstruct the cornerstones around which were developed the fundamental ideas of the Renaissance military mentality. In other words, it is possible to identify some exemplary virtues and behaviours ascribable to the perfect condottiero or to the perfect soldier, and the symbols that embodied these virtues. Then, the spectrum of investigation may be expanded by the comparison between these sources and the military and moral treatises of the Renaissance; thus, the extent at which the measure of the idealization of the behaviours present in the treatises has permeated the everyday life of the soldier can be observed.

For Braccio da Montone, I refer to the chronicle of his life written by Giovanni Antonio Campano around 1458, and the following vulgarisation made by Pompeo Pellini at the end of XVI century. Campano dedicated his work to Braccio's son, Carlo Fortebracci, and collected the information about Braccio's life and deeds through the testimonies of Braccio's veterans, the bracceschi. Campano's chronicle shows an effort of symbolic sublimation of the main character, which

1 On Braccio see: Braccio da Montone e i Fortebracci. Le compagnie di ventura nell'Italia del XV secolo, Narni, 1993; On Sigismondo see: TABANELLI, 1977; FALCIONI, 2006; ZAMA, 1965, pp. 131-193; FrANCESCHINI, 1973, pp. 311-388; YRIARTE, 1882. On Federico see: FRANCESCHINI, 1961 and 1970, pp. 431-544; TOMMASOLI, 1978; De LA SizerAnNe, 1972. On Giovanni see: CARDInI, 2001a, pp. 148-179; SCALINI, 2001b, pp. 180-201.

2 About the humanistic historiography see: Di Stefano, 1992. About the genre of commentarii see: IANZITI, 1992, pp. 1029-1063. 
becomes the representative of the virtue par excellence, the military virtue, "a new virtue which can be identified with the military art. From here, the encounter between this biography and the genre of the de arte militari treatises can be noticed through an accurate reading." 3 The most interesting chronicle about Sigismondo is the one written by Gaspare Broglio Tartaglia da Lavello; son of the famous condottiero Tartaglia da Lavello and educated to the profession of arms, Gaspare served Sigismondo as ambassador, captain and political advisor since 1443 until the death of Sigismondo (1468), and was eyewitness of most of the narrated event. ${ }^{4}$ For Federico di Montefeltro the more detailed biography is the one composed by Pierantonio Paltroni after 1470. Instructed to write the captain's biography, Paltroni has followed Federico in every military campaign since 1439; he was therefore present at the narrated events and recounts them with a not overstated partisan spirit. ${ }^{5}$ In the end, about Giovanni de' Medici the most interesting source are the letters written by Pietro Aretino, ${ }^{6}$ who followed Giovanni since 1525 and was a witness of his last days. Furthermore, the biographies written in the XVI century by Giovan Battista Tedaldi (1495-1575) have to be taken into account, who personally served Giovanni, and by Gian Girolamo Rossi (1505-1564), bishop of Pavia. ${ }^{7}$ These biographies and chronicles must be amended by various quotations taken from contemporary authors and chronicles.

In conclusion, in the space of this article it is not possible to analyse, not even with a summary, the army's structure or the Renaissance Italian warfare, for which I refer to the studies in the footnote. ${ }^{8}$

3 TATEO, 1990, p. 114. On this subject see also: FINZI, 1993, pp. 37-59, and the introduction by Valentini in CAMPANO, 1929.

4 The Cronaca Malatestiana is extracted from the unpublished Cronica Universale. See the item BROGLIO, Gaspare, in: Dizionario Biografico degli Italiani, Treccani.

5 About the life of Paltroni see the introduction to the publication of his commentarii written by Walter Tommasoli: PALTRONI, 1966, pp. 9-28.

6 About Pietro Aretino see: LARIVAILLE, 1980.

7 TeDALDI, 1833, pp. 11-18; Rossi, 1833.

8 Del TREPPO, 1973, pp. 253-275 and 2001, pp. 417-452; PIERI, 1952 and 1966, pp. 99-119; ANCONA, 1973, pp. 643-665; STORTI, 1997, pp. 257-271; Mallett, 1974, 1988, pp. 257-271, and 2007; Del Negro, 2001; Contamine, 1986; Waley, 1993, pp. 111-128; CARDini, 2001b, pp. 8-41; ARFAIOLI, 2005, pp. 1-27. 


\section{The virtue of Fortitudo}

Necessarily, the analysis of the soldier's body and its risks is interlaced with the XIV and XV century moral and military literature, and therefore with the moral virtues that are submitted to the ideal military action. Contamine, in his La guerre au Moyen Âge, has sketched a preliminary history of the courage, analysing its description in some treatises and identifying the concept of courage with the virtue of fortitude. ${ }^{9}$. Fortitudo is one of the four cardinal virtues, according to the system invented by Plato, in which the fortitude, often combined with the courage, is the one that grants resoluteness and tenacity in difficulties. Tommaso d'Aquino pinpointed fortitude as the strength in the line of duty that is the virtue which makes the man intrepid in front of any danger. In the laical context, fortitude is the typical characteristic of the strong man who does not hesitate in front of enemies or obstacles, and is therefore often associated to the military world. In the military context, fortitudo have to deal, at the same time, with the fear of death and with bravery and for this reason, both boldness and military skills derive from fortitude. ${ }^{10} \mathrm{~A}$ suitable example is offered by the Tractatus de bello, de represaliis et de duello written around 1360 by Giovanni da Legnano, an Italian jurist and canon lawyer at the University of Bologna, who was read and printed during the XV century. The professor asserts that war is composed of three elements: brawn, fortitude and weapons. For the author, fortitudo is the most important, since it gives the strength both to assault and to wait the enemies' assault and, therefore, it's a virtue sided between courage and fear. ${ }^{11}$ Military and moral literature played a central role in the definition of the war's virtues and the composition of the perfect soldier's code of conduct. "Many of the legal and military treatises which constituted the framework of a sort of international code of arms in the fifteenth century were Italian. Giovanni da Legnano, Egidio Colonna, and Bartolomeo da Saliceto were amongst the most influential writers and codifiers in the

9 CONTAMine, 1986, pp. 339-351.

10 Fortitudo consists of seven different components: magnanimity, trust, selfconfidence, munificence, tenacity, tolerance (also called patience or resoluteness) and perseverance.

11 See: ERMINI, 1923; DA LEGNANO, Giovanni in Dizionario Biografico degli Italiani, Treccani. 
fourteenth century", even though the XV century produced more practical than theoretical treatises. In the everyday life of the army probably were active conventions formed as "a combination of standard legal codes and long-standing military and chivalric custom", ${ }^{12}$ which relied largely on the captains' model and the competition between soldiers. ${ }^{13}$

In summary, the virtue of fortitudo was rooted within the military culture of the Italian Renaissance, and represented both the courage to resist to the fear and to not give in to the enemy's provocations, and both the courage to rush into the battle without fearing pain, wounds and death. It symbolised the virtue of the soldier who is able to attack but also to wait and to endure deprivations and suffering, without falling prey to the instinct but applying an essentially human rationality. Braccio insisted on this quality of the Italian soldiers during a dispute with Alfonso V d'Aragona in $1423^{14}$ about the differences between Italians soldiers and the foreigner ones:

"I primarily think that the wars do not consist of the number of the soldiers, but of the virtue $[\ldots]$ and this virtue is not ascribed to the sturdiness of the body, but to the spirit's prudence. You [...], like wild beasts, start running into enemies' arms, and you die mostly because of your disorderly fury than because of the virtue of others, and you think that your recklessness has to be celebrated as virtue." 15

12 Mallett, 1974, pp. 205f.

13 About the factors of cohesion within the Italian army see: ZuG TuCCI, 1993, pp. 157-177.

14 On the army of Alfonso d'Aragona, and his dispute with Braccio see the chapter Alfonso V d'Aragona e le armi italiane, in: PIERI, 1966, pp. 91-97. For the entire narration of the fact see: CAMPANO, 1929, pp. 165-168; PELLINI, 1572, pp. 111-114.

15 Pellini, 1572, p. 111: "Io primieramente sono d'oppenione, che le guerre non consistano nel numero de' soldati, ma nel valore, $[\ldots]$ et che questo valore non s'habbia tanto da attribuire alla gagliardezza del corpo, quanto alla prudenza dell'animo. Voi $[\ldots]$ vi date à guisa di fiere precipitosamente correndo nell'armi de' nemici, et morite piu tosto per cagion della vostra disordinata furia, che per prodezza altrui, et giudicate, che s'habbia à celebrare per virtù la vostra temerità". See: FINZI, 1993, pp. 45-50. 
Hence, to possess the virtue of the soldier means to be aware of when it is advantageous to attack and when, instead, it is necessary to wait and placate the instinct and the battle's adrenaline. Again, Braccio makes this idea explicit when he affirmed: "I'm aware that these Germans madly run not just toward the battle, but toward the death, which happens when someone is totally ignorant of the military art, and allow itself to be ruled by its idiotic ferocity." 16 This double connotation of fortitudo as firmness and courage takes largely account of the impulsiveness and instinct; this virtue of the sensitivity's control in the crucial moment of the fought war is part of the soldier's training, and is underlined for example, in the fencing manuals of the XV century. ${ }^{17}$ In fact, it is present in the most famous Italian fencing manual, the Floss Duellatorum by Fiore dei Liberi of Cividale. The treatise, dedicated to Niccolò III d'Este, was written between 1400 and 1409, and includes the sword in one and two hands, in armor, daga, spear etc. In every surviving manuscript, there is an image, called the segno di scherma, or "the seven swords", which presents the seven basic strokes of the sword and the four basic virtues of the fencer. ${ }^{18}$

16 IBID., pp. 113f.: "Io intendo, che cotesti Tedeschi, che voi dite, vanno pazzamente correndo non dirò alla battaglia, ma alla morte, il che è forza, che si faccia quando altri è del tutto ignorante dell'arte della guerra, et si lascia governare dalla sua stolta ferocità".

17 In the space of this article it is not possible to investigate the different perception of the body within the development of the fencing treatises through the XV and XVI century. I would like only to underline that if in the first part of the XV century, following the example of Fiore de' Liberi, the body which applies the sword and military techniques is performing an art, since the end of the century, with the work of Filippo Vadi (1483-87), the body and the swordsmanship are compared to a science associated to music and to geometry: "La geometria e musica comparte/ le loro virtù scientifiche in la spada/ per adornare el gran lume de Marte", RuBboli/ CESARI, 2005, pp. 36f.. This interpretation of the body is well integrated in an arc of development which increasingly understands the body as a machine, starting with the anatomy treatises of the XVI and XVII century. The idea of the swordsmanship as a perfect and calculated science will have its full exemplification in fencing manuals such as the Trattato di Scientia d'Arme by Camillo Agrippa, and the Gran simulacro dell'arte e dell'uso della scherma by Ridolfo Capoferro.

18 Until now were found four different manuscripts: the Getty manuscript, Ludwig XV 13, J.Paul Getty Museum, Los Angeles, California, published in a critical edition by MALIPIERO, 2006; the Morgan manuscript, Morgan MS. M. 383, Morgan Library \& Museum, New York City; the Florius de 
These virtues are embodied by four different animals: ${ }^{19}$ forteza (fortitudo) represented by the elephant, presteza (celeritas) represented by the tiger, ardimento (audatia) embodied by the lion and, in the end, avisamento (prudentia) embodied by the lynx. The gloss of fortitude says: "I am the elephant and I have a castle as cargo, and I do not kneel or lose my place." 20 The fencer (and the soldier) must share the qualities that the elephant symbolised during the Middle Ages, namely justice, patience, obedience and both physical and moral strength. Drawn positioned under the feet of the magister, fortitude is the first and basic virtue a fencer must learn during its education. This iconography of the elephant as representative of fortitude had a wide diffusion. For example, it fulfills a double symbolic function in the medals by Matteo de' Pasti and some anonymous of Rimini made for Sigismondo Malatesta on the occasion of the inauguration of the Malatestian Temple. On the downside of these medals, dated 1446 and 1447, the personification of fortitudo sustained by two elephants is represented, which were both the heraldic animals of the Malatesta family and both the animal representation of fortitude. ${ }^{21}$

arte luctandi Miss. Latin 11269, Bibliothèque nationale de France, Parigi; the Pisani-Dossi manuscript, Floss Duellatorum in armis, sine armis, equester et pedester, now in a private collection, published in a critical edition by RAPISARDI, 2008. In this article I refer to the Getty manuscript.

19 The comparison to the animal world, and to the different qualities and virtues attributed to them, was very frequent. For example, in the Arte Gladiatoria dimicandi by Filippo Vadi (although written on the basis of the Floss) the virtues of the fencer are embodied by other animals, namely the bear, the ram, the snake and the greyhound. See: RuBbOLI/CESARI, 2005, pp. 61f.. On the interpretation of the animals see: PASTOUREAU, 2012.

20 "Ellefante son e un castello porto per chargo / e non mi inzinochio ne perdo vargo", Ludwig XV 13, f. 32r, J.Paul Getty Museum, Los Angeles, California.

21 Reproductions n. 5-6-7-8 in: CAlabi/ CoRnaggia, 1927, pp. 38f.. See also the marble medallion representing fortitudo with the same characteristics inside the Malatestian Temple in Rimini, probably made by Antonio di Duccio, in: IBID., n. 3, p. 47. The concept of fortitudo was dear to the cultural framework of Sigismondo, as he wrote in one of his sonnets: "La lima rode el ferro, l'acqua i marmi/ Per lo spesso cader de l'alto tecto,/ el continuo bussar spezza omne muro./ Non debb'io adonca al tucto abandonarmi,/ Ma porger sempre prieghi al duro pecto,/ Sperano che fia umile ben che sia duro.", TURCHINI, 1985, p. 12. 
Hence, fortitudo is the virtue of resisting and enduring, but it is also the virtue of the courage to attack and to hold the enemy's stare and going into battle. ${ }^{22}$ When debating military practice, the central role played by ferocity and by violence cannot be forgotten. ${ }^{23}$ In this context the virtue represented by the lion in the Floss Duellatorum comes into play: "Nobody has a more brave heart than me lion, and I invite everybody to battle." ${ }^{24}$ If the condottieri have to embody to their soldiers all the virtues that they require, courage and ferocity have to be released at the appropriate time. "All the Princes are creatures of violence, and without it the soldier's ferocity becomes the tameness of a monk. No virtue is looked with more regard by the troops", Pietro Aretino affirmed, "because when it matures the furies which are moving it, it is converted into glory." ${ }^{25}$ In conclusion, the central issue concerning the possession of the virtue of fortitude is not to erase anger and ferocity, but to apply them with rationality, distancing them from an instinctive and beastly attitude, as narrated by Giangirolamo Rossi about a conversation between Giovanni de' Medici and one of his soldiers: "Some were saying to one of his soldiers 'You go bravely that you are right'; and then [Giovanni] said to him 'Do not rely on this, but on your heart, and on your hands, otherwise you will appear like a beast."”26

22 The subject of the ferocious gaze is recurrent, but it cannot be analyzed in this article. For example, Braccio says about the opponent soldiers: "They are not men capable of hold for a long time the gaze of our furious eyes", Pellini, 1572, p. 65. "Non sono però huomini da sostenere lungamente lo sguardo de gli occhi nostri adirati".

23 About violence in the late Middle Ages see: HALE, 1972, pp. 19-37.

24 "Più de mi leone non porta core ardito, pero di bataglia fazo azaschun invito", f. 32r, Ludwig XV 13, J.Paul Getty Museum, Los Angeles, California.

25 "Tutti i Principi son creature della violenza, e senza essa la ferocità del soldato diventa mansuetudine fratesca. Niuna vertù ha in sé la milizia di più riguardo $[\ldots]$ per ciò ch'ella nel maturare i furori che la movano, si converte in gloria". Letter of Pietro Aretino to the captain Vincenzo Bovetto, November 25, 1537, in: ARETINO, 1997, t. I, book I, pp. 349f..

26 Rossi, 1833, p. 171: "Dicendo alcuni ad un suo soldato che andava a combattere: 'va' arditamente, che hai ragione'; egli gli disse: 'non ti confidare in questo, ma nel quore, e nelle mani, altramente parrai una bestia'". 


\section{Deprivations, pain and scars: the interpretation of the soldier's body}

Apart from the ideal virtue, in the everyday practice of warfare and in the soldier's life, fortitude coincided with the endurance of the pain, with the ability to suffer the training in arms and the war's deprivations. In particular the deprivations of the body were a badge of honour for soldiers and their condottieri, since the good training of the soldier corresponded to his ability to endure pain and strain. Jean de Bueil, in Le Jouvencel (about 1466), interpreted war as a school of asceticism, fit for the purpose to get the body used to deprivations, which requires "pain and struggle" and the ability to bear "suffering, dangers, poverty and famines." 27 For this reason, it is easy to notice many references both to their ability to endure, and to the deprivations that they shared with their soldiers in XV century's chronicles and treatises about the good qualities of the condottieri. The exemplary nature of the condottieri's action for their soldiers will be analysed later in this article. For now, it can be noticed how the same themes are proposed in many descriptions and eulogies. The conduct of Sigismondo Malatesta, for example, during the 1448 siege of Piombino, is described by Roberto Valturio in these terms:

"The military seriousness of Sigismondo excelled; in the resistance of the
difficulties of the wakefulness, the thirst, the starvation and of every
hardship $[\ldots]$. He was happy to break the mouldy and black bread with
his soldiers that otherwise would have been thrown to the dogs [...] He
was not nauseate to drink the muddy and sulphate waters; on the contrary
he savoured them so playfully that, by seeing him, the soldiers did not
mind the deprivations of wines and clean waters." 28

The same was written about Sigismondo's greater enemy, Federico di Montefeltro, who was described as "patient about cold and heat, starvation, thirst, sleepiness and difficulties as much as he wanted, without one could presume that any of these things gave him stress or

27 Quoted in: CONTAMINE, 1986, pp. 343f..

28 The passage, quoted in TABANELLI, 1977, p. 75, is taken from De Re Militari, written by Roberto Valturio, book VII, chapter 17. 
bother." ${ }^{29}$ Similar terms are used by Braccio da Montone during the dispute with Alfonso V d'Aragona. Braccio, as reported by Giovanni Campano, describes the soldiers as:

\begin{abstract}
"those who had hardened the body by heat, and cold, those who from childhood are used to sleep in stables, and have learned to suffer dust, wind, hunger, thirst, sleepiness, and others great difficulties, without any pleasure and, raised between enemy's arms, have learned to disregard the wounds, to throw and parry the blows." 30
\end{abstract}

The bond between the condottiero and his soldiers, characterised by respect and imitation, is created therefore through the suffering of the body. In fact, of Braccio is said that

"he did not send his soldiers within troubles, but he went with them in person, and, just like them, he submitted himself in difficulties, starvation, and wakefulness, he gave all the spoils to his own, wanted for himself just glories and the command. Therefore the love, that the army had for him, was born, and the goodwill of the soldiers." 31

29 PAltroni, 1966, pp. 53f.: "patientissimo de freddo et de caldo, de fame, de sete, de sonno et de fadica quanto a lui piacea, senza che si potesse presumere che alcuna de queste cose gli desse afanno o molestia".

30 Pellini, 1572, p. 112: "Quelli, che hanno indurati, et incalliti i corpi dal caldo, et dal freddo, i quali infin dalla fanciullezza si sono avezzi à dormire nelle stalle, et hanno imparato à sopportare la polvere, il vento, la fame, la sete, il sonno, et altre fatiche grandissime, senz'alcun piacere, et allevatisi infra l'armi de' nemici, hanno imparato a disprezzare le ferite, à menare, et à riparare i colpi".

31 Pellini, 1572, p. 20: “Egli non mandava i soldati ne' pericoli, ma v'andava con esso loro in persona, et non meno di loro si sottometteva alle fatiche, alla fame, et alle vigilie, dava tutta la preda à suoi, solo per sé voleva la glorie, et l'imperio. quindi poi nacque quell'amore, che gli portava l'essercito, et la gran benevolenza de' soldati'.

The subject of the difference between glory and spoils, between the motivation of the condottiero and of the soldiers, although of a great interest, is too extended to be analyzed in this article. 
As the final recipient of the war's dangers and pain, the body becomes the cornerstone of the life of the armies, where deprivations, wounds and mutilations were certainties of the profession.

Even though very different from the kind of war that was fought beyond the Alps, "Italian Renaissance warfare was far from bloodless but rarely unnecessarily brutal." 32 The wounds, especially those originated from the new firearms, were common between mercenaries and professional soldiers, therefore more wounds and scars decorated the body of the veteran. This characteristic of the Italian armies is well illustrated by Braccio in the aforementioned dispute with Alfonso, while explaining the peculiarity, or the supposed superiority, of the Italian soldiers. The Italian warfare is more technical, more professional and involves a smaller number of soldiers more expert in the profession of arms, well trained at the military life. "Better is to use a small number of well-trained soldiers, than a malpractice multitude", ${ }^{33}$ Braccio affirmed, criticising the Spanish "bad war", which "represented a concept of total war, a determination to ensure that the enemy did not fight again, which was largely alien to contemporary Italian attitudes to war." ${ }^{34}$ In fact, it was common in the $\mathrm{XV}$ century for the Italian condotte to make an explicit request of soldiers "good, apt, experts, and adequate to the profession of arms." ${ }^{35}$

In this framework of interpretation, the good care of the body, and its training, assumes a key role, due to its double function; on one hand, a fragile body which needed to be protected by an increasingly sophisticated $\operatorname{armor}^{36}$ and, on the other, a strong body reinforced by

32 Mallett, 1974, p. 200.

33 PELLINI, 1572, p. 112: "Meglio è però di servirsi d'un picciol numero bene amaestrato, che d'una mal prattica moltitudine". This idea was already present in Vegezio, when he affirmed that "In every conflict the number is not as useful as the courage", quoted in: CONTAMINE, 1986, p. 341.

34 Mallett, 1974, p. 200.

35 "Buoni, apti, experti et idonei nel mestiero delle armi", 1478, September 10th, Conventions for the condotta of Ercole d'Este, Duke of Ferrara, as general captain of the League between Venice, Milan, Florence and Ferrara. Document written out in full in: CANESTRINI, 2007, doc. n. XXVII, pp. 156164.

36 Putting the life in danger did not correspond to the sacrifice or an absolute devotion, which were concepts aliens to the XV century's military mentality. Therefore the armor's development both for men and horses is originated 
deprivations and battles, which bears the signs of the scars as a testimony of the soldier's value and courage. ${ }^{37}$ Particularly wounds, scars and calluses are fundamental themes in the construction of the fictional speeches of the condottieri to their soldiers, as narrated in the chronicles, at a time when they had to instil courage and pride in his troops. For example, Braccio said to his soldiers before the battle of Sant'Egidio, in the 1416: "[the enemies], accustomed to idleness, will never be able to stand in front of you, who are full of scars and calluses on your faces and on your hands." ${ }^{38}$ Similar words were spoken by the opponent captain, Carlo Malatesta, while was appealing to his soldiers' bravery: "Who turns his back gives to the enemy the chance to strike him without fail. And there are no more dishonoured wounds than those in the back and, on the contrary, none is more honoured than those in the chest and in the face." ${ }^{39}$ It can be noticed how scars were a defined symbol within the military world, which represented virtue, courage and dedication to the profession of arms. One may therefore think that to be injured during the battle was a source of pride among the soldiers. Giovanni Antonio Campano, while composing his biography of Braccio da Montone, relied on the tales and the memories of the condottiero's veterans, the

from this idea, Contamine, 1986, p. 346. About armors and warfare during the Italian wars see: SCALINI, 2001a, pp. 102-147.

37 In the same dispute Braccio affirms: "It also happens, that very few die for our way to battle, therefore, we Italians are all covered in iron, and rarely happens that the blows penetrate at the flesh, or are deadly". PeLLini, 1572, p. 112: "aviene anco, che ne muoiono pochi dal nostro modo d'armare, conciosiacosa, che noi Italiani andiamo tutti coperti di ferro, et rare volte incontra, che i colpi penetrino al vivo, ò siano mortali".

38 PeLLini, 1572, pp. 65f.: "[i nemici], assuefatti ad un lungo otio, non potranno mai stare à fronte con esso voi, pieni di cicatrici, et di calli il volto, et le mani"; CAMPANO, 1929, pp. 97f.: "Veterani si qui "sunt hostium milites, quos ille per oppida disiectos uxoribus enervandos exhauriendosque disperserat, desueta iam bello sunt et longo otio soluta corpora, nequicquam nostris cicatricibus et duratis callo lacertis congressura". The battle took place on July 12th 1416.

39 IBID., pp. 67f.: "chi volta le spalle, da occasione al nemico di poterlo offendere à man salva. ne ci sono feirte più disonorate di quelle di dietro, e per lo contrario, niuna più honorata di quelle del petto, et del viso"; CAMPANO, 1929, p. 99: "Sed qui terga vertit hosti, feriendum se impune offert, nec ulla tam foeda vulnera, quam quae tergo excipiuntur: contra nulla honestior quam adverso in pectore fronteque cicatrix". 
bracceschi; and, it is no accident that, in the narration of the winning battle of Rocca Contrada of 1407, he underlined how two of the most trusted soldiers of Braccio, Spinta and Guglielmo Mecca, received (they and their horses) respectively 105 and 72 wounds, "an event worth of memory for all the people who will come." ${ }^{40}$ Fortitudo, in this case, is the virtue that allows soldiers to endure the enemy's attack, and the pain of the injuries.

This interpretation of scars, endurance and training of the body, and its symbolic meaning, was well known within the Italian military system and played a role even in the selection of the soldiers. In the following extract from the biography of Braccio, Campano (during the narration of the intense military campaign of the 1412-1413) compares the bracceschi to the enemies, praises the veterans' qualities and summarises all the different aspects of the interpretation of the body:

"Most of the enemies were new soldiers, and the bracceschi were all veterans $[\ldots]$. Those were effeminate due to the home's pleasures, they did not dare to see the people in battle, and these, having the bodies hardened by the sun, and the wind, and accustomed to the wounds, did not fear even the blows of the swords. [...] They were more eager for the glory of their captain than of their own profit; and it is sure that he used a wonderful diligence in the selection of soldiers, and he did not want them big and large, so that the horses (as he used to say) would not have been weakened by the heavy weight, but small, and less than of a medium stature, as long as they were strong and violent, and had a soldier's inclination and, above all, he liked the most those who were respectable for the signs of the wounds in the face and who had the other limbs torn by blows." ${ }^{41}$

40 IBID., p. 15: "Un certo Spinta, ch'era stato in fin da fanciullo suo soldato [di Braccio] hebbe trà lui, e'l cavallo, 105 ferite, et guglielmo Mecca 72. Cosa veramente degna di memoria à tutte le genti che verranno". CAMPANO, 1929, pp. 28-29: "Omnes vulnerati, inter quos Spinta quidam, qui sub Braccio iam inde a puero militaverat, una cum equo centum et quinque confossus vulneribus, Gulielmus Mecha duobus et septuaginta. Res omni posteritate memorabilis".

41 IBID., p. 44: "i nemici erano la maggior parte soldati nuovi, et i bracceschi veterani tutti [...]. Quelli finalmente essendo effeminati nelle delitie di casa, non ardivano di veder le genti in battaglia, et questi havendo i corpi indurati 
The visible scars in the face are, therefore, a material demonstration of the soldier's virtue, as an ability to suffer and endure blows and wounds. In other words, they display the awareness of the human body's fragility but, at the same time, also the capacity to endure pain, to tackle and to overcome it, regenerating the spirit in the same way the skin does with the scars. "The skin, 'the man's shell', is a particularly rich field; place of exchange between the body's inside and outside, organ of touch, it constantly reveals its vulnerability, its receptivity to blows and cuts, but also its formidable regeneration skill: the skin is a permanent source of life." ${ }^{42}$ The skin, hence, the face's skin in particular, becomes an identification sign, a canvas on which are incised the soldier's characteristics, a means to the revelation of someone's virtues. "Therefore, the skin it's a piece that worth for the whole. Surely is the casing, the sack in which the body mass resides, namely the bone structure, the flesh and the blood; but it is also fundamentally what characterises and identifies." ${ }^{43}$ The scars in the face, in fact, were one of the recommended aspects useful to the identification and registration of the foot soldier, in the first years of the XVI century, as we can read in

dal sole, et dal vento, et assuefatti alle ferite, non temevano pure i colpi delle spade. [...] Erano più desiderosi della gloria del lor capitano che del lor proprio guadagno; et certa cosa è, ch'egli usava una maravigliosa diligenza nella elettion de' soldati, ne gli voleva grandi, et grossi, affine che i cavalli (come egli solea dire) dal troppo gran peso non s'indebolissero, ma piccioli, et meno che di mediocre statura, purche fossero robusti et gagliardi, et che havessero buona presenza di soldato, et gli piacevano sopra tutti gli altri coloro, che fossero stati riguardevoli per li segni delle ferite del volto, et che dalle percosse havessero lacerate l'altre membra del corpo."; CAMPANO, 1929, pp. 70f.: "Hostium plerique tirones, Bracciani veterani omnes [...]. Denique illis emolliti domesticis deliciis animi ferri aciem expavescebant; Braccianis durata sole ventoque et plena vulneribus corpora ne ictus quidem gladiorum formidabant [...]. Nam illud quoque constat, in militibus deligendis singulari usum diligentia; nec magnos aut procer, ne, quod dicere solebat, equos nimio fatigarent pondere, sed breves et infra mediocres, robustos tamen ac 'bonae habitudinis conducere libentius consuesse; maxime omnium quos adversa fronte cicatrices et deformata plagis ac vulneribus membra, insignia bellicae virtutis, notarent".

42 GÉLIS, 2000, p. 103.

43 IBID., pp. 110f.. 
the Avvertenze ai Dieci di Balia. ${ }^{44}$ So, as can be noticed, this framework of interpretation of the suffering of the body, and in particular of scars and wounds, was well established within the Renaissance military mentality, as stated by Pietro Aretino, while was comforting Giovanni de' Medici on his deathbed, reminding him that "The wounds and the loss of limbs are the necklaces and the medals of the family members of Mars." 45

\section{"Non feci mai cose indegne di me" 46 The condottiero and his example through suffering, death and the body.}

The just described cultural frame of mind was valid both for the soldiers and the captains; condottieri had to lead and command the soldiers through respect, fear and example, showing their acknowledgment of the displaying of the soldiers' virtues and, at the same time, had to provide prove that they embodied all the qualities requested from the troops. It has already been noticed, with the previous examples, how the condottiero submitted himself to the deprivations of war, together with his soldiers. Now it is interesting to highlight how this just described cultural approach implicated the need of a continuous manifestation of bravery by the condottieri; furthermore how, in the a posteriori tale of their deeds, these men are transformed into exemplary soldiers, thanks to a narrative process in which the body keeps to play a key role.

The captain was a role model for his soldiers and, to ensure that the troops would have followed him into battle, he had to become an example

44 Around 1500, Avvertenze ai Dieci di Balia per la condotta dei Conestabili al tempo della guerra di Pisa. About the way to register the foot soldiers is written: "I would like that, as first thing, it will be written the name of that particular soldier, and the name of his father, and his place; and then the time that he has; what weapons he carries; and then his height, and it will be written as many signs as he has on the face". Document written out in full in: CANESTRINI, 2007, doc. n. LXI, pp. 258-268.

45 "Le ferite e la perdita dei membri, sono le collane e le medaglie de i famigliari di Marte". Letter from Pietro Aretino to Francesco de gli Albizzi, December 10th 1526, in: ARETINO, 1997, t. I, book I, p. 55.

46 See note n. 74. 
of bravery and be at the head of his troops, thus demonstrating his boldness and the absence of fear of pain and wounds. Since the bravery of an isolated man is insufficient to achieve victory, the condottiero must draw, through the example, the moltitudine into battle; therefore, the individual's courage becomes everyone's courage.

"If the soldiers see the captain hesitant, irresolute, and distrustful of his own strength, they cannot, under any circumstances, keep themselves for fleeing, but if they see him full of ardour, and of hope, cheerfully approaching the army, urging the soldiers to fight, they do not have any fear, even if they would find themselves in great and evident danger." ${ }^{27}$

From these words, attributed to Angelo della Pergola, it can be noticed that the condottiero must have been not only fearless but, to be able to lead the soldiers, he had also to desire the battle and to show his urge to fight. This scenario happened during the battle of Monteluro, fought on December 8, 1443, ${ }^{48}$ when Sigismondo Malatesta (at the time condottiero of the general captain Francesco Sforza), led his soldiers against the troops of Niccolò Piccinino, although Sforza did not want to engage:

"[Sigismondo] trembled in his mind because he wanted to engage battle [with a captain of Niccolò Piccinino], and sent the trumpeters to his camp so that every man would have get on his horse. [...] Sigismondo, passionate and eager for going against the aforementioned captain, had this thought, and then put it in place, and mounted on the horse with his helmet in his head, with some of his men, ferociously went to find the captain of Niccolò Piccinino [...]. And [Francesco Sforza] went to

47 Pellini, 1572, p. 13: "Il capitano, il quale, se i soldati veggono esser timido, irresoluto, et diffidente delle sue forze, non possono per niuna diligenza del mondo ritenersi dalla fuga, ma se all'incontro lo veggono tutto pieno d'ardire, et di speranza, andare allegramente intorno all'essercito, essortando i soldati à combattere, non hanno alcun timore, etiandio se in grave et manifesto pericolo si vedessero".

48 For a report of the battle in the contemporary chronicles see: PALTRONI, 1966, pp. 63-65; SimONETTA, 1934, pp. 132-134; ANONIMO RiMinESE, 1922, p. 95; GIOVANNI PEDRINO, 1986, p. 207. 
separate them and he could not do it, because Sigismondo was impetuous due to his ardour." 49

Sigismondo and his troops achieved a great victory, thanks to the quick attack, "and first for Sigismondo's virtue; but not that his lordship was not wounded." $"$ So it is during this fearless ride into the battle, when the condottiero shows his disregard for pain and wounds that the bond between the captain and the soldiers grow stronger. "What captured the heart of his troops, was that, in troubles, he was saying 'Follow me' and not 'Go in front of me", ${ }^{51}$ told Pietro Aretino about Giovanni de' Medici and the Black Bands. This attitude had the power, as outlined in Angelo della Pergola's speech, to instill courage and bravery into the soldiers, creating a spirit of excitement and restlessness, well described in the verses of the XV century anonymous poem about the battle of Aquila: "They heard the captain's speech/ Who is coward becomes paladin./ They all shouted: 'we are already come to blows by now,/ And we will see who is not violent." "52 Hence, the virtues are manifested, obviously, through the actions, but also through the signs these actions leave on the soldier's body. Therefore, more scars testify greater virtue and courage and, for this reason, the condottieri are expected to be more decorated

49 Broglio, 1982, pp. 107f.: "Nella sua mente [Sigismondo] tucto fremiva de volerse atacare co' lui [un capitano di Niccolò Piccinino], e mandò al suo canpo i suoi trombetti che ogni homo montasse a cavallo. [...] inanimito lo illustrissimo signore miser Sigismondo e aceso di volontade d'andare a trovare el prefato capitano, e facto dicto pensiero, lo mise assequitione, e montato a cavallo col suo elmetto in testa, con alquanti di suoi andò ferocemente a trovare lo prefato capitano di Niccolò Piccinino [...]. e andò la signoria sua per distacarlo e non podè, per che lo illustrissimo signore miser Sigismondo inanimato più e'l acendiva".

50 IBID.: "Prima per la vertù hoperata per lo prefato signore miser Sigismondo di Malatesti; non però che sua signoria non fosse ferita".

51 "E quel che tirava a sé il core de le genti sue, era il dire ne i pericoli 'Venitimi dietro', e non 'Andatimi innanzi'”. Letter from Pietro Aretino to Francesco de gli Albizzi, December 10th 1526, in: ArETiNo, 1997, t. I, book I, p. 58.

52 ANONIMO, 1935, p. 143: "Odenno lo parlar dello capetano/ Deventa paladinu chi è codardu./ Grydano tucty: 'Omay sciamo alle mano,/ Et vederasse chi non è galliardo"'. The oratory talent of the condottieri is another subject dear to humanism, but it cannot be analyzed here. 
with scars and wounds. One more time, Braccio's words during his dispute with Alfonso make explicit this framework of interpretation:

\begin{abstract}
"Those, who exceed all the others for virtue, courage and faith and are followed by soldiers, captains and colonels, are our Generals and captains of the Italian armies. And there is nothing, which they are feeling more proud of, than to show a great quantity of wounds in the chest, and the body all lacerated by scars." ${ }^{53}$
\end{abstract}

So, through condottieri's body images and quality descriptions, this consideration for the scars within the military mentality, also as a valid symbol in the development of the relationship between the captain and his troops, can be realised one more time. Again, it is said of Giovanni de' Medici that "He testified his love for the army, embellishing his legs, limb and the chest with the signs printed by arms." ${ }^{54}$ As a summary of this two aspects of the captain's courage, namely to lead by example and to endure pain and wounds, stands Federico di Montefeltro's actions during the battle of San Fabiano, fought on July $221460.5^{55}$ Two days earlier, Federico suffered a sprain to the loins during a skirmish and "nowise he could move or go, but he was like dead and had such pain and passion that it was a marvel." 56 Then, the command passed to

53 Pellini, 1572, pp. 113f.: "Quelli, che avanzano tutti gli altri di virtù, di valore, et di fede, sono seguiti dà soldati, dà capitani et dà Colonnelli, et questi sono i nostri Generali, et capitani de gli esserciti Italiani. Ne cosa alcuna è, di che essi più honorati si tengano, che del mostrare una gran quantità di ferite nel petto, et il corpo tutto lacerato dalle cicatrici"; CAMPANO, 1929, p. 168: "Hi sunt imperatores nostri: haec italica imperia. Nullum preclarius insigne quam vulnerum adverso pectore moltitudo et deformata cicatricibus corpora".

54 "Era il testimonio de l'amore che portava a la milizia, ricamandosi le gambe, le braccia e il busto con i segni che stampavano l'armi". Letter from Pietro Aretino to Francesco de gli Albizzi, December 10th 1526, in: Aretino, 1997, t. I, book I, p. 58. See also the aspect's description of Braccio in: Pellini, 1572, pp. 93f.; CAMPANO, 1929, pp. 142f..

55 See the report of the battle written by the chancellor of Alessandro Sforza in: ANONIMO VERONESE, 1915, pp. 140f..

56 PALTRONi, 1966, p. 149: "In su'l mover del cavallo, che se mosse disconcio, el conte Federico prese una storta et una doglia alli lumbi, che vulgariter se chiama el mal del dilombato, che per niuno modo si potea moviere né 
Alessandro Sforza who, on July 22, was attracted into battle by the opponent captain Jacopo Piccinino. Federico's troops were finding themselves on a disadvantageous field of battle and started to retreat. Federico "was feeling so much pain that he had no spirit to climb on his horse; nonetheless he had himself mounted on the horse in the best way possible and in a great pain", and with four squires he arrived at the field. "And due to his arrival the troops found spirit, solace and big hope [...] not without enormous danger for his person because, without wearing his armour, he struggled where the soldiers were not safe, and his horse was wounded and damaged, and he was alive thanks to a miracle." ${ }^{57}$

In conclusion, on the subject of the exemplar captain, it is interesting to linger on the deaths of Braccio da Montone and Giovanni de' Medici. Without probing the extended and complicated interpretation of Renaissance funeral rituality, ${ }^{58}$ it is useful to underline the role played by the condottieri's manifestation of wounds and mutilations, and the effect this display had on the contemporaries and in the later literary transpositions. In the battle of Aquila, fought on June 2 1424, Braccio was mortally wounded in the neck by an anonymous soldier, carried to the enemy camp where he remained for three days inside of the opponent captain's pavilion, Jacopo Caldora, ${ }^{59}$ where he was visited by captains, doctors and soldiers. He spent his last days refusing any doctors'

andare, se non como quasi fusse morto et stava cum tanta doglia et passione che era una maraviglia".

57 IBID., pp. 153-155: "La doglia lo apresava per modo che non li bastava l'animo a montare a cavallo; pure si fece mectere a cavallo el meglio possette et cum grandissima doglia"; "Et per la venuta sua li suoi ne presero animo, conforto et speranza grandissima [...], non senza grandissimo pericolo de la sua persona perché, senza arme indosso, se adoperò dove li armati non istavano securi, et fo ferito et guasto el cavallo che havia sotto, et fu miraculo che lui non fusse morto". The battle of San Fabiano is narrated in SER GuERRIERO DA GUBBIO, 1902, pp. 70f.: "El signore conte era in lo alogiamento amalato; el quale sentendo li soi havere el peggio et quasi messi in volta, così amalato se fecie porre a cavallo". See also: PICCOLOMINI, 1984, pp. 747-749. See also: TOMMASOLI, 1978, p. 137.

58 On this subject see: ARIÉs, 1980; SALVESTRINI/VARANINI/ZANGARINI, 2007; Zug TuCCI, 2007, pp. 243-274.

59 For a description of the battle in the contemporaries sources see: BROGLIO, 1982, p. 40; ANONIMO RimineSE, 1922, pp. 57-58; PELLINI, 1572, pp. 139142; CAMPANO, 1929, pp. 203-205; SimONETTA, 1934, pp. 17-20; ANONIMO, 1935, pp. 187-227. 
remedies, food or drink, without speaking to anybody; he remained silent in the display of his mortal wounds to anybody who wanted to admire them, "as if he did not want the enemies to have of himself more than a silent body." ${ }^{60}$ Braccio died at the age of 56 , in a way that drove his biographer to wonder the reasons of his silence: "But either he did not hear, or he faked not to hear, he never answered to him [Jacopo] nor to others with a single word, either because his deep and mortal lesions took out his spirit, or because, although the fate had given his almost lost body in the enemies' will, nonetheless he felt undefeated in his soul." ${ }^{\prime 61}$ Wether the silence was caused by the wounds or by Braccio's stubbornness in demonstrating his virtue to the victorious enemy, his death struck the soldiers and the contemporaries deeply. The soldiers' attachment to their captain is well illustrated in the circumstances of his last days, when:

"A lot of his soldiers [...] (while he was still alive) went to visit him and comfort him, but they never got him to speak or eat something"; "These discontent and quite soldiers, during the night, were seen to go in the enemy pavilion, and during the day (since it was permitted to them) they surrounded Braccio's bed touching him, gazing at him, and sighing; and

60 Pellini, 1572, p. 139: "Et havendo già passato tre giorni interi senza mangiare et senza bere et senza pur mai dire una parola, quasi non volendo che i nemici havessero di se in poter loro altro, che un corpo mutolo". An excellent and in-depth analysis of Braccio's death, of the different causes of his silence and of the meanings of the death in battle can be found in: ZUG TuCCI, 2001, pp. 143-163.

61 Pellini, 1572, p. 140: "Ma egli o che non udisse, ò che fingesse di non udire, non rispose mai, nè a lui, ne ad altri pur una minima parola, ò perché le mortali et profonde piaghe gli havesero tolto il sentimento, o perché quantunque la fortuna havesse dato in poter de' nemici il suo già quasi perduto corpo, egli nondimeno ritenesse ancora seco l'animo invitto"; CAMPANO, 1929, pp. 203f.: "Exemptum equo et intra tabernaculum subductum, benigne aut non audientem aut audire nolentem est affatus. Sed ne unum quidem elicere quisquam potuit verbum, vel quod alte descendentes mortiferae plagae vim omnem sensumque exhauserant, vel ut, quoniam fortuna victum corpus in potestatem hosti tradidisset, animum sibi invictum ipse retineret. [...] Sed destinatus ad mortem animus omnem medicamentorum opem respuebat. Quippe totum 'triduum sine cibo, sine potu, mutus cum egisset, incertum vulneribus an inedia, est extinctus, anno aetatis sexto et quinquagesimo". 
when they came out from the pavilion, they covered their heads and cried, and made the enemies cry as well." 62

And when he finally died, "Illo mortuo, totis castris secutum silentium." ${ }^{63}$ His silence became everyone's silence and through his body Braccio became a representation of virtue, acknowledged both by his soldiers and by the enemies; his wounds were the tangible sign of military attitude, a mentality based on courage, example and control over the body and the pain, which permeated his army and his military school and was handed down through the following generations of soldiers and condottieri. The new techniques that Braccio introduced within the military practice (based on a smaller number of well-trained soldiers, on quick attacks and the continuous use of reserves) described by Giovanni Antonio Campano, contain all the four virtues of the fencer mentioned above about the Floss Duellatorum. A military strategy which relies on the war skills of the soldiers, who have to be carefully recruited and continuously trained by (and through) the war's deprivations, in which we can spot fortitudo; a strategy based on the condottiero's virtue, his promptness (celeritas) and his courage to lead the troops into battle (audatia); finally, a technique which makes extensive use of prudentia,

62 IBID. pp. 139f.: "Molti de' suoi soldati [...] andarono (mentre egli ancora spirava) à visitarlo, et confortarlo, ne mai poterono ottener da lui, ch'egli parlasse, ò che si ricreasse almeno alquanto col cibo"; "Questi, venuta la notte, tutti malcontenti et queti, si vedevano andare intorno al padiglione nemico, et il giorno (poi ch'era loro permesso di farlo) gli circondavano il letto, toccandolo, rimirandolo, et sospirandogli intorno et quando uscivano dal padiglione, copertisi il capo, et piangendo, facevano uscir le lacrime dagli occhi etiandio a' nemici".

63 CAMPANO, 1929, p. 205: "Illo mortuo, totis castris secutum silentium, quasi plus esset in amisso doloris, quam laetitiae in capto. Eius milites, qui aut proelio superfuerant aut ab hostibus erant dimissi, plerique, facta potestate, spirantem adhuc consolandi gratia adierunt, remotisque arbitris, 'ut vocem tolleret utque cibum sumeret hortati, nihil profecerunt. Nec ullum in ducem tantus militum amor. Illi tabernaculum hostis noctu maesti ac taciti perlustrare, illi interdiu, facta quotiens vellent potestate, frequentes ad lectum perstare, tangere, intueri, suspirare cernebantur, et ubi tabernaculo excessissent, obvoluto capite plorantes, nulli non hostium lacrimas excutiebant". 
in order to avoid the unforeseen and to risk as few lives as possible, distrusting the empty and ferocious temerity.

Like Braccio, Giovanni of the Black Bands found his death due to a wound in battle. He was the general captain of the papal army during the war of the League of Cognac that lasted from 1526 to 1530 . In a battle with the landsknechts leaded by Georg von Frundsberg, ${ }^{64}$ Giovanni was hit by a shot of falconet in the right leg. The battle took place in Governolo, near Mantua, on November 25, 1526. ${ }^{65}$ Giovanni was transported to Mantua, to the palace of Aloioso Gonzaga (lord of Castel Goffredo), and there medicated by Doctor Abramo Ariè (the personal doctor of Federico II Gonzaga, duke of Mantua). After a couple of days the doctor decided to amputate the wounded leg. Despite that, Giovanni died on the night of November 30 at the age of 28 . The news of his death echoed throughout all of Italy, and everyone that reported the fact underlined Giovanni's conduct during his last days. ${ }^{66}$ In particular, the fact that he did not want to be held by anyone during the leg amputation and his ability to endure such pain and torment. The most reliable sources are the letters of Pietro Aretino, who eye-witnessed the event: "The doctors send to find eight or ten men to hold Giovanni steady while they were violently sawing, 'Not even twenty (Giovanni said smiling) could hold me'. He went there with determined look, and he took a candle in his hand, so he could make light onto himself, and I ran away." ${ }^{67}$ All the contemporary chronicles agree on Giovanni's endurance of the pain, like in Rossi's biography, where it is written that "While they were sawing,

64 About the landsknechts see: BAUMANN, 1996.

65 About the Italian war in the first years of the XVI century see: PIERI, 1952, pp. 536-593.

66 About the last days of Giovanni and his funeral: CISERI, 2001, pp. 202-221. See also: SCALINI, 2001c, pp. 222-229.

67 "Dissero si trovassero otto o dieci persone che lo tenessero mentre la violenza del segare durava. 'Né anco XX (disse egli sorridendo) mi terrebbero'. Recatosi là con fermissimo volto, presa la candela in mano, nel far lume a se medesimo, io me ne fuggı": letter from Pietro Aretino to Francesco de gli Albizzi, December 10th 1526, in: ARETINO, 1997, t. I, book I, pp. 55f.. 
he did not want to be tied up nor held steady by anyone, enduring that torture with great tenacity", ${ }^{68}$ or in Tedaldi's:

\begin{abstract}
"The doctors at last decided to saw off his leg, and he suffered with great tenacity without being held by anyone, and then he wanted to see the amputated leg, that was carried to him in a silver bucket, he stared at it saying 'I, for this and other things, utterly thanks God [...] and if I will not be able to carry out the profession of arms by feet, I will carry it out on the horse." $" 69$
\end{abstract}

Giovanni personifies the perfect condottiero who patiently suffers huge pain, so much so that, to prove his courage, Aretino said that he "laughed while cutting the nerve." 70 The biographies, though, are not unanimous about what Giovanni has done with the amputated leg: if Tedaldi said that he wanted to see it, Rossi affirms that "he set it on fire and he wanted it in his hand"; ${ }^{71}$ Marin Sanudo recounts "messer Zanin de' Medici had sawed off his leg, and he picked it up in the hands swearing vengeance." 72 I believe that Giovanni's reaction to the amputation, and how it was perceived by his contemporaries, provides a good example of how wounds and pain could be symbolised and become an expression of military virtue. Giovanni's sawed-off leg is a concrete symbol that conveys his bravery and fortitudo, his predisposition to command and the deserved loyalty of his soldiers. From this perspective, the fact that "he wanted to have his foot with the piece of his leg fetched to himself, laughing on us, because we could not stand to see what he had

68 Rossi, 1833, p. 172: "Mentre gliela segavano non volse esser legato, né tenuto da alcuno, sopportando tal martorio costantissimamente".

69 TEDALDI, 1833, p. 98: "I medici per ultimo si risolverno a segargli la gamba, la qual senza voler esser tenuto, sopportò con animo costante, e volse dipoi vederla segata, la quale portatagli in un bacino d'argento, fissamente riguardò dicendo: 'Io dì questa cosa, et d'ogni altra cosa ringratio sommamente quel vero Dio [...] et se io non potrò fare il mestiere delle armi a piedi, lo farò a cavallo"".

70 "Rise nel tagliarsi il nerbo": letter from Pietro Aretino to Francesco de gli Albizzi, December 10th 1526, in: ArETinO, 1997, t. I, book I, p. 56.

71 Rossi, 1833, p. 172: "Datogli fuoco la volle in mano".

72 SANUdo, 1969-1979, vol. XLIII, col. 348: "Di Mantoa, fo lettere del Marchese, di 28, al suo orator. Come al signor Zanin di Medici era stà taià la gamba, la qual tolse in man zurando vendetta". 
suffered", ${ }^{73}$ becomes an additional demonstration of virtue that the condottiero reveals through his relationship with the body, the scars and the pain.

Giovanni, a young and ambitious captain deeply connected to his Black Bands, until the last moments of his life claimed his own personal research of the perfect military virtue; in fact, in front of the confessor who was arrived to his sickbed, Giovanni said: "Father, because I am a professor of arms I lived according to the soldier's custom, but I would have lived like the religious, if I had worn the clothes that you wear. And were it not that it is not legit, I would confess in front of each, because I never did things unbecoming of me." ${ }^{\prime 4}$ For Giovanni the virtue resides "in the honourable fulfilment, and above all technically irreproachable, of the chosen profession. We are in the presence of a real moral of the action". If the Aretino's words are "expression of the moral of a group rather than of an individual moral", ${ }^{75}$ they are therefore expression of the military mentality that I tried here to preliminarily investigate; a mentality which makes a key point of the devotion to the profession and of the sacrifice of the body to the honour of the soldier and of the visible scars the materialisation of the so praised military action. Until the last moment, he was faithful to his soldier's nature and wanted to die in a camp bed; he died as an example of the soldier whose virtue can do nothing against the "cowardice" of the fire arms, of the abominioso ordigno $;{ }^{76}$ his tormented body as symbol of the implacable changes of the practice of war.

73 "Si faceva portare oltra il piede con il pezzo de la gamba, ridendosi di noi, che non potevamo sofferire di vedere quello che egli aveva patito": letter from Pietro Aretino to Francesco de gli Albizzi, December 10th 1526, in: ARETINO, 1997, t. I, book I, p. 56.

74 IBID.: "Padre, per esser io professor d'armi son visso secondo il costume de i soldati, come anco sarei vivuto come quello de i religiosi, se io avessi vestito l'abito che vestite voi. E se non che non è lecito, mi confessarei in presenza di ciascuno, perché non feci mai cose indegne di me".

75 Quotations taken from: LARIVAILLE, 1980, p. 85.

76 In Ludovico Ariosto's Orlando Furioso (canto IX, octaves 90-91) Orlando throws the arquebus in the sea, deploring the advantage that it grants against the enemy, addressing it with these words: "Acciò più non istea/ mai cavallier per te d'esser ardito,/ né quanto il buono val, mai più si vanti/ il rio per te valer, qui giù rimanti./ $\mathrm{O}$ maladetto, o abominoso ordigno,/ che 
Finally, I would like to briefly touch upon the rivalry between Sigismondo Malatesta and Federico di Montefeltro and mention how, during one of the many moments in which they confronted each other, the corporeity and the symbolism of pain operated as clear provocations, according to the military framework of interpretation illustrated above. It is impossible here to retrace the landmarks, which have constellated a rivalry and an hatred that lasted a lifetime. ${ }^{77}$ Simplified: throughout their entire lives, they were sworn enemies, due to be lords of adjacent territorial states, always commanding opposite armies which were used to steal castles and lands to one another. In the spring of 1457, Borso d'Este, duke of Modena, had promoted a meeting between the two lords with the purpose of reconciliation, in order to stop a feud that could have damaged the recently achieved peace of Lodi of 1454 . The meeting, which took place in the castle of Belfiore on May 6 and $7,{ }^{78}$ is narrated in the commentarii of Pierantonio Paltroni. The author insists that Sigismondo's complaining about leg pain caused by a fall from his horse, underlined his unwillingness to make peace with Federico, and understands it as a provocation to the Duke of Urbino. In fact, he affirms: "Sigismondo did not ride [towards Federico at his arrival in Belfiore] because he had a little leg pain; which was not true, but Sigismondo faked it, and he had no pain at all." ${ }^{.79}$ Due to Sigismondo's inability, the Duke

fabricato nel tartareo fondo/ fosti per man di Belzebù maligno/ che ruinar per te disegnò il mondo,/ all'inferno, onde uscisti, ti rasigno".

77 About this subject see: a letter from Federico to Francesco Sforza of November 51451 in FRANCESCHINI, 1961, pp. 92-94; an insulting letter of Sigismondo against Federico in FrANCESCHINI, 1970, pp. 445f.; the letter from Federico in reply of the insult in FRANCESCHINI, 1956, pp. 46-49; a letter from Sigismondo to Giovanni de' Medici of December 24 1451, in Yriarte, 1882, pp. 425f.. See also: PALtroni, 1966, p. 51; De LA SIZERANNE, 1972, pp. 45-120.

78 About the meeting of Belfiore in the contemporary sources see: GIOVANNI Di M. PEDRINO, 1986, p. 310; ANONIMO VERONESE, 1915, p. 91; BALDI, 1824, vol. 1, pp. 179-183 and vol. 2, pp. 8-29; SER GuERriero DA GubBIO, 1902, pp. 66-67. See also the letter from Borso d'Este to his ambassador in Milan, Ugolotto Facino, of May 1457, written out in full in: SoRANZO, 1911, pp. 466f..

79 This and all the following quotations are taken from the complete narration of the event in: PALTRONI, 1966, pp. 113-124. "Sigismondo non era 
of Modena asked to Federico to accompany him to Sigismondo's chamber. "Then together went to Sigismondo's chamber, but he did not wait for them to go up to his room and, well showing that he had leg pain, helping himself with a stick, he went down to a loggia, and there he met the Duke of Modena and Federico. $"{ }^{80}$ Often in the past, Sigismondo had accused Federico of cowardice and of avoiding direct conflicts and duels, although Federico was wounded and lost an eye during a joust in $1450^{81}$ (which weakened his military performances). Again on this occasion, Sigismondo was exploiting the leg pain as a demonstration of painful valour (as much as Federico and his scars in the face) on one hand, and on the other hand was mocking the Duke of Urbino by implying his lack of commitment in the frontline.

The subtle provocation of Sigismondo was abundantly noticed by the participating and exacerbated even more, if possible, the attitudes. The reconciliation started with Sigismondo and his famigli, who arrived "with weapons at side, like those who deliberated to do everything but words [...] or frighten others." 82 After a long discussion constellated by reciprocal teasing, Sigismondo provoked Federico, implying his cowardice and Federico answered sarcastically; then the meeting ended up in a disaster, with swords drawn and reciprocal insults: "Rising up with hands on his weapon, Sigismondo said 'For the body of God, I'll remove your guts from your body'. The Count, rising up similiter 'And I

cavalcato perché havea un poco male a una gamba: la qual cosa non era vera, ma finse el signore Sigissmondo havere male, ma non havea male niuno".

80 IBID.: "De compagnia se ne andarno inverso la camera del signore Sigissmondo, el quale non aspectò però che andassero su a la camera ma, mostrando pure che la gamba li dolesse, apogiandose ad un bastone, venne giù a una loggia che ce era, et illi incontrò el signore Duca de Modena et el conte Federico".

81 About the injuring of Federico see: BALDI, 1824, vol. 1, p.198; FRANCESCHINI, 1970, pp. 462-464. About the duels between Sigismondo and Federico see the letter from Sigismondo of February 211445 written out in full in TABANELLI, 1977, pp. 50-52, and Federico's answer in OsiO, 1970, vol. 3, part II, n. 317, pp. 363-365. About the honor of the duel see: CAVINA, 2005.

82 PAltroni, IBID.: "Haveano a lato le arme assai giuste, como quilli che haveano deliberato fare altro che parole $[. .$.$] o mictere paura da altri”.$ 
will take away your innards." 83 After the considerations made throughout this article, it is easier to understand how the pain showed by Sigismondo was seen such an annoying provocation to Federico. In their personal, military and political rivalry, Sigismondo leads also the conflict on a symbolic level, in which he tried to embody a moral and military superiority through the show of the leg pain (fake or not), knowing that his provocation would have been acknowledged by Federico, who shared with him the same military mentality.

\section{Conclusions}

In a world that strives to remove the pain from the body, to protect the soul's sack which accompanies the man throughout his journey on earth, to proudly show the suffering of the body becomes a tangible demonstration, almost ascetic, of their own moral qualities. In the everyday normality of the bodies marked by diseases and, therefore, by weakness, the signs of the wounds and of the battle become a manifestation of moral and physical strength. The system of values in force within the Renaissance military life identified in the wounds the strength, the courage to face the pain and to overcome it; the same courage that was needed to face the battle and the war's deprivations, namely that fortitudo which was so dear to the military and moral treatises.

On the pain, the wounds, the resistance and the deprivations, the training and the suffering, as well as on the joys, is developed and strengthened the relationship between the condottiero and the soldiers; the awareness to each possess a sensitive body, which dies and suffers in the same way, puts in contact and unites. Through the body, its dangers and its pleasures, through a sensitive, material and visible experience, through the memento of their own deeds incised on the skin, is formed the special relationship between the condottiero and his veterans.

On the contrary, on the instinct's rationalization and on the discipline of the body, as well as on the manifestation of a superior ability to endure

83 IBID.: "El signor Sigissmondo alora, levandose su cum le mane in su l'arme, disse: 'Per lo corpo de Dio, io te cavarò le budelle dal corpo'. Et el Conte disse, levandose similiter: 'Et io te cavarò la corada a te'”. 
pain and a minor fear to feel it, is formed the reputation and the virtue of the condottiero. Between the basic requirements useful to command the troops, pain, courage, rationality and generosity are parts of a cultural framework, which places the materiality of the body and its sensitive perception at the center of a theoretical system of virtues. A body which has to be showed to others, which, since childhood, has to be educated to patience and strength, which has to suffer and to overcome suffering so it can become a symbol of the perfect military virtue; a virtue that can grant by itself the unique desire of the condottieri, that is to earn a name that will be consecrated to posterity.

\section{Bibliography}

\section{Sources}

ANONIMO, Cantari sulla guerra aquilana di Braccio, ed. by ROBERTO VALENTINI, Roma, 1935.

ANONIMO RIMINESE, Cronache Malatestiane del secolo XIV e XV, ed. by ALDO FRANCESCO MASSERA, in: Rerum Italicarum Scriptores, volume XV, part II, Bologna, 1922.

ANONIMo Veronese, Cronica, ed. by GiovanNi Soranzo, Deputazione veneta di storia patria, Venezia, 1915.

Aretino, Pietro, Lettere, ed. by PAOLO Procaccioli, volume I, book I, Roma, 1997.

BALDI, BERnARDINO, Vita e fatti di Federigo di Montefeltro duca di Urbino Istoria, vol. 1-2-3, Roma, 1824.

Broglio Tartaglia, Gaspare, Cronaca Malatestiana del secolo XV (dalla Cronaca Universale), ed. by ANTONIO LUCIANI, Rimini, 1982.

CAmpano, Giovanni ANTONIO, Bracci Perusini vita et gesta ab anno 1368 usque ad 1424, ed. by RoBERTO VALENTINI, in: Rerum Italicarum Scriptores, volume XIX, part IV, Bologna, 1929.

CANESTRINI, GIUSEPPE, Documenti per servire alla storia della milizia italiana dal XIII secolo al XVI, raccolti negli archivj della Toscana e preceduti da un discorso di Giuseppe Canestrini, Ruggello, 2007.

FIORE DE' LIBERI, Floss Duellatorum in armis, sine armis, equester et pedester, ed. by GIOVANNI RAPISARDI, Torino, 2008. 
Giovanni Di M. Pedrino, Cronica del suo tempo, ed. by Gino BorgheZIO/MARCO VATTASSO, volume II, Roma, 1986.

MALIPERIO, MASSIMO, Il Fior di Battaglia di Fiore dei Liberi da Cividale (Il Codice Ludwig XV 13 del J. Paul Getty Museum), Udine, 2006.

Osio, LuIGI (ed.), Documenti diplomatici tratti dagli archivj milanesi e coordinati per cura di Luigi Osio, Milano, 1970.

Paltroni, Pierantonio, Commentari della vita et gesti dell'illustrissimo Federico Duca d'Urbino, ed. by WALTER TOMMASOLI, Urbino, 1966.

Pellini, PomPEO, L'Historie et Vite di Braccio Fortebracci detto da Montone, et di Nicolo Piccinino perugini, Venezia, 1572.

Piccolomini, ENeA Silvio or PIO II, I Commentarii, ed. by LUIGI TOTARO, Milano, 1984.

Rossi, Giangirolamo, Vita di Giovanni de' Medici celebre capitano delle bande nere, in: Notizie dei secoli XV e XVI sull'Italia, Polonia e Russia, raccolte e pubblicate da Sebastiano Ciampi colle vite di Bona Sforza de' duchi di Milano regina di Polonia e Giovanni de' Medici detto delle Bande Nere, Firenze, 1833, pp. 135-180.

SANUdO, MARIN, I Diarii, Bologna, 1969-1979.

SER Guerriero DA GubBIO, Cronaca dall'anno 1350 all'anno 1472, ed. by GIUSEPPE MAZZATINTI, in: Rerum Italicarum Scriptores, volume XXI, part IV, Città di Castello, 1902.

SimonetTA, GIOVANNI, Rerum Gestarum Francisci Sfortiae

Commentarii, ed. by GIOVANNI SORANZO, in: Rerum Italicarum Scriptores, volume XXI, part III, Bologna, 1932-34.

TEDALDI, GIOVAN BATTISTA, Discorso sulla nobiltà e virtù di Giovanni de' Medici, in: Notizie dei secoli XV e XVI sull'Italia, Polonia e Russia, raccolte e pubblicate da Sebastiano Ciampi colle vite di Bona Sforza de' duchi di Milano regina di Polonia e Giovanni de' Medici detto delle Bande Nere, Firenze, 1833, pp. 89-101.

TURCHINI, ANGELO (ed.), Isotta bella sola ai nostri giorni, sonetti d'amore di Sigismondo Pandolfo Malatesta, Rimini, 1985.

VADI, FILIPPO, L'Arte Cavalleresca del Combattimento, ed. by MARCO RubBoli/LuCA CESARI, Rimini, 2005. 


\section{Literature}

Ancona, Clemente, Milizie e condottieri, in: Storia d'Italia, vol. 5, Torino, 1973, pp. 643-665.

ARfaioli, MaURIZIO, The Black Bands of Giovanni. Infantry and Diplomacy during the Italian Wars (1526-1528), Pisa, 2005.

ARIÉs, PHILIPPE, L'uomo e la Morte dal medioevo a oggi, Roma-Bari, 1980.

BAUMANN, REINHARD, I Lanzichenecchi: la loro storia e cultura dal tardo Medioevo alla guerra dei Trent'anni, Torino, 1996.1

Calabi, Augusto/ Cornaggia, Gianluigi, Matteo dei Pasti. La sua opera medaglistica distinta da quella degli anonimi riminesi del XV secolo in relazione ai medaglioni malatestiani aggiunte le falsificazioni, Milano, 1927.

CARDINI, FRANCO, Giovanni gentiluomo, in: Giovanni delle Bande Nere, ed. by MARIO SCALINI, Firenze, 2001a, pp. 148-179.

ID., La crisi militare e la politica italiana fra Quattrocento e Cinquecento, in: Giovanni delle Bande Nere, ed. by MARIO SCALINI, Firenze, 2001b, pp. 8-41.

CAVINA, MARCO, Il sangue dell'onore: storia del duello, Roma, 2005.

CISERI, ILARIA, Gli ultimi giorni di Giovanni delle Bande Nere, le esequie e il ritorno del suo sepolcro a Firenze, in: Giovanni delle Bande Nere, ed. by MARIo SCALINI, Firenze, 2001, pp. 202-221.

Contamine, PhilipPe, La guerra nel Medioevo, Bologna, 1986.

De La SizeranNe, RoBert, Federico di Montefeltro: capitano, principe, mecenate (1422-1482), Urbino, 1972.

Del Negro, Piero, Guerra ed eserciti da Machiavelli a Napoleone, Roma, 2001.

DEL TREPPO, MARIO, Gli aspetti organizzativi, economici e sociali di una compagnia di ventura italiana, in: Rivista Storica Italiana, fasc. 3, Napoli, 1973, pp. 253-275.

ID. (ed.), Condottieri e uomini d'arme nell'Italia del Rinascimento, Napoli, 2001.

ID., Sulla struttura della compagnia o condotta militare, in: Condottieri e uomini d'arme nell'Italia del Rinascimento, ed. by MARIO DEL TREPPO, Napoli, 2001, pp. 417-452. 
Di StEFANO, ANITA et al. (ed.), La storiografia umanistica, convegno internazionale di studi, Messina 22-25 ottobre 1987, Messina, 1992.

ERMINI, GIUSEPPE, I trattati della guerra e della pace di Giovanni da Legnano, Imola, 1923.

FALCIONI, ANNA (ed.), La signoria di Sigismondo Pandolfo Malatesti: la politica e le imprese militari, vol. 2, Rimini, 2006.

FINZI, ClaUdio, Una "vita" di Braccio di Giannantonio Campano, in: Braccio da Montone e i Fortebracci. Le compagnie di ventura nell'Italia del XV secolo, Atti del convegno internazionale di studi, Montone 23-25 marzo 1990, Narni, 1993, pp. 37-59.

FRANCESCHINI, GINO, La prima giovinezza di Federico di Montefeltro ed una sua lettera ingiuriosa contro Sigismondo Pandolfo Malatesta, in: Atti e Memorie della Deputazione di storia patria per le Marche, 11, Ancona, 1956, pp. 27-75.

ID., Federico di Montefeltro. Dalla concessione del vicariato apostolico alla pace di Lodi 1447-1454, Sansepolcro, 1961.

ID., I Montefeltro, Varese, 1970.

ID., I Malatesta, Varese, 1973.

GÉLIS, JACQUES, La spoglia dell'uomo. Contributo all'immaginario della pelle, in: Corpi. Storia, metafore, rappresentazioni tra Medioevo ed età contemporanea, ed. by ClaUdio PANCINO, Venezia, 2000, pp. 102-120.

Hale, John RigbY, Violence in the late Middle Ages. A background, in: Violence and civil disorders in Italian cities, 1200-1500, ed. by LAURO MARTINES, Berkley et al., 1972, pp. 19-37.

IANZITI, GARY, I "Commentarii": appunti per la storia di un genere storiografico, in: Archivio Storico Italiano, CL, disp. IV, Firenze, 1992, pp. 1029-1063.

Larivaille, Paul, Pietro Aretino fra Rinascimento e manierismo, Roma, 1980.

Mallett, Michael, Mercenaries and their Masters. Warfare in Renaissance Italy, London, 1974.

ID., Il condottiero, in: L'uomo del Rinascimento, ed. by EUGENIO GARIN, Roma-Bari, 1988, pp. 43-72.

ID., L'organizzazione militare di Venezia nel '400, Roma, 2007.

Pastoureau, Michel, Bestiari del Medioevo, Torino, 2012.

PIERI, PIERO, Il Rinascimento e la crisi militare italiana, Torino, 1952. 
ID., La scienza militare italiana del Rinascimento, in: Scritti vari, Torino, 1966, pp. 99-119.

ID., Scritti vari, Torino, 1966.

SALVESTRINI, FRANCESCO et al. (eds.), La morte e i suoi riti in Italia tra Medioevo e prima età Moderna, Firenze, 2007.

SCALINI, MARIO, Tecniche e tecnologia nelle guerre d'Italia, in: Giovanni delle Bande Nere, ed. by MARIO SCALINI, Firenze, 2001a, pp. 102147.

ID., Condottiero, cavaliere o soldato?, in: Giovanni delle Bande Nere, ed. by MARIO SCALINI, Firenze, 2001b, pp. 180-201.

ID., I resti dell'armatura funebre di Giovanni delle Bande Nere e alcuni oggetti a lui legati, in: Giovanni delle Bande Nere, ed. by MARIO SCALINI, Firenze, 2001c, pp. 222-229.

SoRANZO, GIOVANNI, Pio II e la politica italiana nella lotta contro i Malatesti. 1457-1463, Padova, 1911.

STORTI, FrANCESCO, Istituzioni militari in Italia tra Medioevo ed età Moderna, in: Studi Storici, XXXVIII/1, Roma, 1997, pp. 257-271.

Tabanelli, Mario, Sigismondo Pandolfo Malatesta. Signore del Medioevo e del Rinascimento, Faenza, 1977.

TATEO FRAnCeSCO, Storia esemplare di un condottiero: la "Vita di Braccio" di Giovanni Antonio Campano, in: TATEO, FrANCESCO, I miti della storiografia umanistica, Roma, 1990, pp. 99-120.

TOMMASOli, WALTER, La vita di Federico da Montefeltro. 1422/1482, Urbino, 1978.

WALEY, DANIEL, I mercenari e la guerra nell'età di Braccio da Montone, in: Braccio da Montone e i Fortebracci. Le compagnie di ventura nell'Italia del XV secolo, Atti del convegno internazionale di studi, Montone 23-25 marzo 1990, Narni, 1993, pp. 111-128.

YRIARTE, CHARLES, Un condottiere au XV siecle. Rimini; études sur les lettres et les arts à la cour des Malatesta, d'après les papiers d'État des archives d'Italie. Avec 200 dessins d'après les monuments du temps, Paris, 1882.

ZAMA, PIERO, I Malatesti, Faenza, 1965.

Zug TuCCI, HANNELORE, Fattori di coesione dell'esercito tra Medioevo ed età Moderna, in: Braccio da Montone e i Fortebracci. Le compagnie di ventura nell'Italia del XV secolo, Atti del convegno 
internazionale di studi, Montone 23-25 marzo 1990, Narni, 1993, pp. 157-177.

ID., La morte del condottiero: Braccio, i Bracceschi e altri, in: Condottieri e uomini d'arme nell'Italia del Rinascimento, ed. by MARIO DEL TREPPO, Napoli, 2001, pp. 143-163.

ID., Morte e funerale del condottiero, in: La morte e i suoi rituali in Italia tra Medioevo e prima età moderna, ed. by FRANCESCO SALVESTRINI et al., Firenze, 2007, pp. 243-274. 